\title{
Calculation of the digestibility for ruminants of roughages from the contents of cell-wall constituents
}

\author{
BLANCHE D. E. GAILLARD \\ Laboratory for Animal Physiology, Agricultural University, \\ Wageningen, The Netherlands
}

\section{Summary}

From 29 roughages with a wide variety of apparent digestibility of the organic matter a regression equation was derived for calculating this digestibility from the contents of lignin, cellulose, hemicellulose and anhydro-uronic acid. The correlation coefficient was 0.95 and the residual standard deviation 3.2. When lignin alone or crude fibre were used as independant variables these values were 0.89 and 4.3 , and 0.87 and 4.7 , respectively.

An easy method for the determination of these constituents was given.

\section{Introduction}

As the energetic value of a roughage in ruminant metabolism is closely related to the digestibility of its organic matter, it is important to be able to predict this digestibility as accurately as possible. The crude fibre value which was first used for this purpose has well known disadvantages, one of them being that different equations are needed for different roughages. The crude fibre is an empirical value which combines digestible and indigestible parts of the food. A fundamental knowledge of the constituents which influence the digestibility of a roughage and of their resistance and interaction during the digestion of the food by the rumen microorganisms may lead to a chemical analysis from which the apparent in vivo digestibility of the organic matter can be calculated more accurately.

It is obvious that the digestibility of a roughage is strongly influenced by its content of the cell-wall constituents lignin, cellulose and hemicelluloses. Of these three components lignin has the greatest influence as it is itself indigestible and physically inhibits the digestion of the enclosed cell nutrients. A high degree of correlation has been found between the digestibility of the organic matter of roughages and their lignin contents (LANCASTER, 1943; Forbes and Garrigus, 1950; Sullivan, 1955; LAUBE, 1960).

Cellulose and hemicellulose are both digested to a certain extent. The digestibility of these polysaccharides varies a great deal partly because of the lignin present but also for other reasons. Some authors have, therefore, investigated the correlation of the digestible organic matter or dry matter with the digestible part of the cell-wall: either the holocellulose (ELY and MOORE, 1959) or the lignin together with cell-wall

Received for publication: April 19, 1966. 
polysaccharides; examples of this latter approach are (a) lignocellulose (JARRIGE, 1961) and $(b)$ the concentration of lignin in lignocellulose together with total cell-wall substances and soluble cell contents (VAN SoEST, 1965). In these investigations the hemicelluloses are either determined together with the cellulose (holocellulose, cell-wall substances) or not at all (lignocellulose). It has been shown, however, that the digestibility of the hemicelluloses is often different from that of the cellulose and may strongly influence the digestibility of the organic matter of a roughage. LyFord et al. (1963) found that with alfalfa the "cellulosan" was less digestible than the alpha cellulose whilst for fescue the reverse was true. JARRIGE and Minson (1964) state that the digestibility of the cell-wall carbohydrates (hemicelluloses and cellulose) may vary greatly. These authors also investigated the relationship between the digestible organic matter and the digestibility of crude fibre, cellulose, lignocellulose, and hemicellulose, respectively. It appeared that hemicellulose digestibility was more closely correlated to the organic matter digestibility than was that of the others. In this connection the ratio of hemicellulose to cellulose is known to be different for different plants and WaITE et al. (1964) also showed that during growth there was a fall in the ratio of cellulose to hemicellulose.

As apparently lignin, cellulose and hemicellulose contents vary greatly in different roughages and as they influence digestibility in different ways it is reasonable to consider them separately in an attempt to predict digestibility. Of these three fractions the hemicelluloses are the most complicated in that they are composed of a mixture of different polymers, some linear (xylans) and some highly branched, which may quite easily have different digestibilities. A difference in ratio of one to the other of these polymers may therefore also have to be taken into consideration. Thus WaITE et al. (1964) found that during growth the hemicelluloses and particularly the xylan fraction which contains uronic acid in its side chains became progressively less digestible. Further, other work (GaIllaRd, 1962) provided evidence that grass and clover hemicelluloses differed in their digestibilities possibly because of differences in structure. In order to check this suggestion a study was made of the monosaccharide composition of the three main hemicellulose polymers (the linear polymer from hemicellulose $\mathbf{A}$ and the linear and the branched polymer from the hemicellulose $B$ fraction) from Gramineae and Leguminosae (GAILLARD, 1965). Distinct structural differences were indeed found between corresponding polymer fractions from each group, especially in the linear xylan from the hemicellulose $A$ fraction and in the branched polymer from the hemicellulose $B$. The action of rumen microbial enzymes on these isolated polymer fractions, from grass and clover, was also studied in vitro using enzyme extracts from (a) mixed rumen bacteria (GAILLARD et al., 1965) and $(b)$ the rumen ciliate Epidinium ecaudatum (BAILEY and GAILlARD, 1965). Rates of action were plotted as increases in reducing sugars, liberated from the polysaccharides, with time. The figures obtained thus indicated two things:

1. The three polymers from grass are hydrolysed by both types of enzymes at a higher rate than are the corresponding polymers from clover. This is in agreement with the results described by GAILlaRD (1962) where the apparent digestibility of the organic matter of legumes was inferior to that of grasses with the same content of xylan (the major component of the hemicelluloses).

2. The branched B polymers from both grass and clover are the most resistant to the action of the enzymes. The rate of hydrolysis of the linear A polymers is somewhat greater and the linear B polymers are broken down the most rapidly. This means that the hemicelluloses from roughages will be better digested when they con- 
tain more of the linear B polymer and it should be noted that the ratio of hemicellulose $A$ to $\mathbf{B}$ differs between various plants and at different stages of growth. Of further interest is the fact that cellulose digestibility also seems to be influenced by the associated hemicellulose. PACKET et al (1965) showed with in vitro experiments that the digestibility of the cellulose in a roughage was reduced upon addition of isolated hemicellulose B. As it was found (GAILLARD, 1964, unpublished), during the isolation of the different polymers, that the hemicellulose $B$ fraction usually contained only small amounts of branched polymer the action of the hemicellulose $B$ on cellulose digestibility is almost certainly attributable to the linear B polymer. It seems therefore important not only to determine the total hemicellulose content of a roughage but also to indicate the amount of linear $B$ polymer in it. As the less digestible hemicellulose components, branched $\mathrm{B}$ and linear $\mathrm{A}$ polymers, contain the highest amounts of anhydro-uronic acid, a uronic acid determination added to the determination of total hemicellulose would provide some information about its composition.

\section{Present investigation}

The four determinations required for the calculation of the digestibility of the organic matter of a roughage can be carried out in a simple analysis after elimination of fat and soluble cell contents. Instead of using the time consuming procedure of extraction with an azeotropic mixture of etinanol-benzere for $30 \mathrm{~h}$ and treatment of the residue overnight with pepsin-hydrochloric acid, the method of van SOEST (1963) for preparing total cell-wall substances by boiling with neutral detergent was chosen. On part of this neutral detergent residue (N.D.R.) uronic acid was determined by titration. For this titration the carboxyl groups should be in the acid form so the N.D.R. was treated with $0.1 \mathrm{~N}$ hydrochloric acid for one half hour and carefully washed free from acid before final drying with acetone. Another part of the N.D.R. was hydrolysed with $\mathrm{N}$ sulphuric acid and filtered. In the filtrate reducing sugars were determined as xylose and calculated as anhydroxylose (hemicellulose). This determination does not include the uronic acid of the hemicellulose as the aldobiuronic acid is resistant against hydrolysis with $\mathrm{N}$ sulphuric acid and only the xylose of it is reducing. The amount of anhydro-uronic acid found by titration has, therefore, to be added to the amount of anhydroxylose found. The residue after drying with acetone was hydrolysed with $72 \%$ sulphuric acid and after diluting to $5 \%$ boiled for some time and finally when still hot filtered over an ashfree filter. In the filtrate reducing sugars were determined as glucose and calculated as anhydroglucose (cellulose). The crude lignin on the filter was dried and incinerated to correct for mineral matter.

In this way lignin, cellulose, hemicelluloses and anhydro-uronic acid were determined on 29 roughages (Gramineae and Leguminosae) with a wide variety of digestibilities.

\section{Materials and methods}

\subsection{S a m ples}

The roughage samples were obtained from digestion trials with wethers carried out at the Institute for Farm Animal Feeding Research at Hoorn, which also provided the data on the digestibilities of the organic matter. On all roughages the digestibilities quoted are the averages of the results obtained with three wethers. 


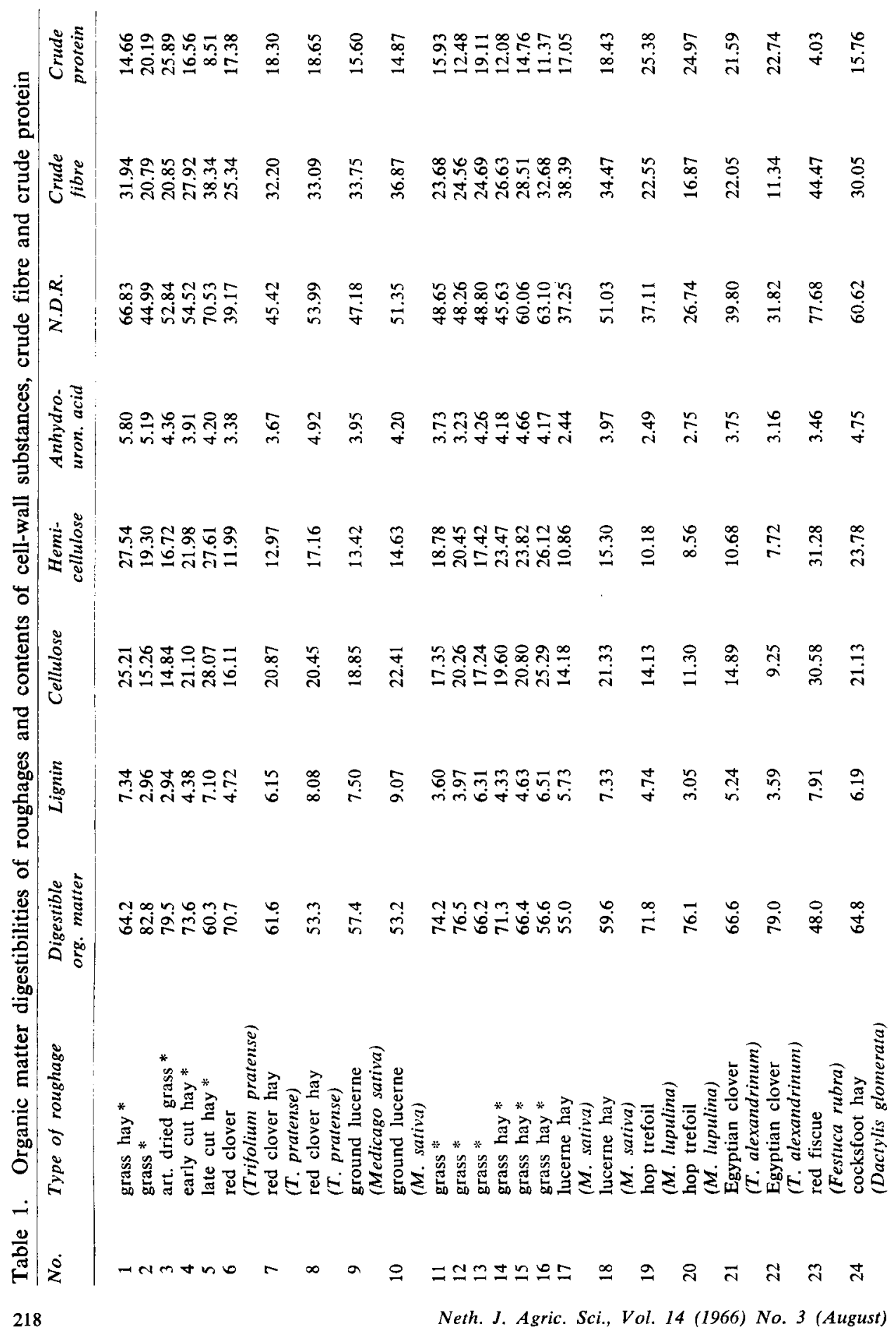




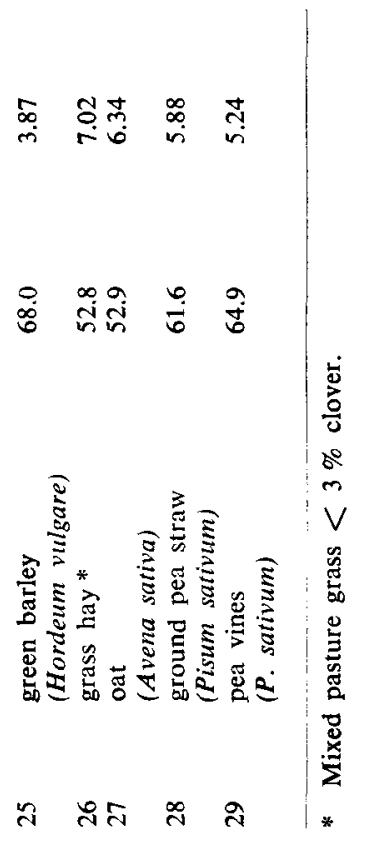




\subsection{R e a ge n $t s$}

1. Neutral detergent solution: add $30 \mathrm{~g}$ sodium laurylsulphate, $18.61 \mathrm{~g}$ disodium dihydrogen ethylenediaminetetraacetate, $4.56 \mathrm{~g}$ disodium hydrogenphosphate and $6.81 \mathrm{~g}$ sodium borate decahydrate to 11 of distilled water and agitate to dissolve. Check the $\mathrm{pH}$ of the solution to be within the range of 6.9-7.1. Adjust with conc. $\mathrm{HCl}$ or $\mathrm{NaOH}$ as necessary.

2. Decalin reagent grade.

3. $0.1 \mathrm{~N}$ hydrochloric acid.

4. Acetone reagent grade.

5. N sulphuric acid.

6. $72 \%$ sulphuric acid.

7. $0.1 \mathrm{~N}$ hydrochloric acid (made with $\mathrm{CO}_{2}$-free water).

8. $0.1 \mathrm{~N}$ sodium hydroxide (made with $\mathrm{CO}_{2}$-free water).

\subsection{Determination}

\subsubsection{Determination of hemicellulose, cellulose and lignin}

$2 \mathrm{~g}$ of the air-dry sample was boiled for $1 \mathrm{~h}$ under reflux with $200 \mathrm{ml}$ of the neutral detergent solution after $4 \mathrm{ml}$ of decalin was added to prevent foaming.

The supernatant was poured whilst hot over a weighed sintered glass filter of wide porosity (Jena G2). The residue in the flask was washed with $0.1 \mathrm{~N}$ hydrochloric acid once and decanted over the filter. The residue was then treated with $0.1 \mathrm{~N}$ hydrochloric acid for $1 / 2 \mathrm{~h}$ and washed free from acid with distilled water. The first washings were decanted over the filter and finally the whole residue was transferred to it. It was washed with acetone, dried by suction and residual acetone evaporated away overnight. The dry residue (N.D.R.) was weighed and calculated as a percent of the original roughage dry matter which had been measured separately.

$0.250 \mathrm{~g}$ of the N.D.R. was hydrolysed by boiling with $50 \mathrm{ml}$ of $\mathrm{N}$ sulphuric acid for $3 \mathrm{~h}$ under reflux. The mixture was filtered when still hot over a paper filter and the residue washed with water. The filtrate was made up to $250 \mathrm{ml}$ and $25 \mathrm{ml}$ of it neutralized and made up to $100 \mathrm{ml}$. From this latter solution 2, 3, 4 and $5 \mathrm{ml}$ samples were taken for the determination of the reducing power by the method of Hagedorn and Jensen using xylose as a standard. The hemicellulose was calculated as anhydroxylose (xylose $\times 0.88$ ) as a percentage of the roughage dry matter augmented with the percentage of anhydro-uronic acid found by titration.

The residue on the filter was dried with acetone and hydrolysed for $4 \mathrm{~h}$ with $3.75 \mathrm{ml}$ of $72 \%$ sulphuric acid at $20^{\circ} \mathrm{C} \pm 2$. Care was taken that all lumps were broken up and the mixture was frequently stirred. The mixture was transferred into a $250 \mathrm{ml}$ flask with $139.5 \mathrm{ml}$ of water, boiled for $2 \mathrm{~h}$ under reflux, filtered when still hot over a weighed ashfree filter and washed with water. In the filtrate the reducing power was determined as described above but using glucose as a standard. The cellulose was calculated as anhydroglucose (glucose $\times 0.90$ ) as a percentage of the roughage dry matter.

The residual lignin on the filter was dried at $100^{\circ} \mathrm{C}$, weighed and incinerated at $500{ }^{\circ} \mathrm{C}$. The weight of the lignin was found by difference and also caluclated as a percentage of the roughage dry matter.

\subsubsection{Determination of anhydro-uronic acid}

$0.300 \mathrm{~g}$ of the N.D.R. was stirred for some minutes with $0.1 \mathrm{~N}$ sodiumhydroxide 
( $\mathrm{CO}_{2}$-free). The excess sodiumhydroxide was titrated with $0.1 \mathrm{~N}$ hydrochloric acid using phenolphthaleine as indicator. $1 \mathrm{ml}$ of $0.1 \mathrm{~N}$ sodiumhydroxide used $=17.6 \mathrm{mg}$ of anhydro-uronic acid. The anhydro-uronic acid was also calculated as a percentage of the roughage dry matter.

\section{Results and discussion}

The contents of lignin, cellulose, hemicellulose, anhydro-uronic acid and N.D.R. determined on the 29 roughages are given in Table 1 together with the digestibilities of the organic matter and the contents of crude fibre and crude protein determined at the Institute for Farm Animal Feeding Research.

For this material the digestibility of the organic matter was regressed on several sets of independent variables. From the resulting residual standard deviations it was deduced which of these sets was to be preferred. The sets used were: lignin + hemicellulose + cellulose + anhydro-uronic acid $(I)$; lignin + cellulose + hemicellulose + anhydro-uronic acid + protein (2); lignin alone (3) and crude fibre (4).

The set which included lignin, cellulose, hemicellulose and anhydro-uronic acid appeared to be superior to that consisting of lignin alone or of crude fibre. Including protein in the first set did not improve the result.

In Table 2 the correlation coefficients and the residual standard deviations are shown. From the residual sum of squares after mean it could be seen that the influence of lignin was the strongest, as was to be expected. The influence thereafter of the cellulose and hemicellulose levels was relatively small and the influence of the anhydrouronic acid content again considerable. As the influence of cellulose and hemicellulose was small it was thought that perhaps instead of lignin + cellulose + hemicellulose the N.D.R. content could be used together with the anhydro-uronic acid content. If this could be confirmed it would shorten the analysis considerably. For N.D.R. + anhydro-uronic acid (5) a correlation coefficient was found of only 0.59 and a residual standard deviation of 7.8. Apparently the separate determination of lignin, cellulose and hemicellulose is needed for an accurate calculation of the digestibility of the organic matter of a roughage.

The regression equation found on this material was as follows:

D.O.M. $=-5.51(\mathrm{~L}-5.58)+0.37(\mathrm{C}-19.19)-0.51(\mathrm{H}-18.10)+4.11(\mathrm{U}-3.80)+65.1$

in which D.O.M. = \% digestible organic matter; $\mathrm{L}=$ lignin, $\mathrm{C}=$ cellulose, $\mathrm{H}=$ hemicellulose and $\mathrm{U}=$ anhydro-uronic acid all in $\%$ of the roughage dry matter.

This equation can probably be used for roughages of different origin and with a wide variety of digestibility as the material from which it was derived showed these two characteristics.

Table 2. Correlation coefficients and residual standard deviations

\begin{tabular}{|c|c|c|c|c|c|c|c|}
\hline$\ldots$ & & —.... & $\ldots$ & $\ldots \ldots$ & & $\begin{array}{l}\text { Correlation } \\
\text { coefficient }\end{array}$ & $\begin{array}{l}\text { Standard } \\
\text { deviation }\end{array}$ \\
\hline Organ. & matter & digestibility & $\ldots$ & - & $\mathrm{L}+\mathrm{C}+\mathrm{H}+\mathrm{U}(l)$ & 0.95 & 3.2 \\
\hline , & $"$ & , & $\ldots \ldots \ldots \ldots$ & - & $\mathrm{L}+\mathrm{C}+\mathrm{H}+\mathrm{U}+\mathrm{P}$ & 0.94 & 3.2 \\
\hline$"$ & $"$ & $"$ & $\ldots \ldots \ldots$ & - & $L(3)$ & 0.89 & 4.3 \\
\hline$"$ & $"$ & , & $\ldots \ldots \ldots$ & - & C.F. (4) & 0.87 & 4.7 \\
\hline$"$ & $"$ & $"$ & $\ldots \ldots \ldots$ & - & N.D.R. + U (5) & 0.59 & 7.8 \\
\hline
\end{tabular}




\section{ACKNOWLEDGEMENTS}

The author wishes to thank Ir. A. J. H. van Es for performing the statistical caiculations, the mathematical department of the Agricultural University, Wageningen, for the use of their I.B.M. computer, Dr. N. D. Dijkstra for providing the roughage samples and the data on their organic matter digestibilities and Mrs. D. H. I. Pierie-Estourgie for technical assistance.

BAILEY, R. W. and Gaillard, B. D. E.

ELY, R. E. and MOORE, L. A.

FORBES, R. M. and Garrigus, W. P.

Forbes, R. M. and Garrigus, W. P.

Gaillard, B. D. E.

Gaillard, B. D. E.

Gaillard, B. D. E., BaILeY, R. W. and Clarke, R. T. J.

JARRIGE, R.

JARRIGE, R. et MINSON, D. J.

LANCASTER, R. J.

Laube, W.

LYFORD, S. J., SMART, W. W. G. and Matrone, G.

Packet, L. V., PlumLEe, M. L., Barnes, R. and MotT, G. O.

Soest, P. J. van

SOEst, P. J. VAN

Sullivan, J. T.

\section{REFERENCES}

1965 Carbohydrases of the rumen ciliate Epidinium ecaudatum (Crawley). Hydrolysis of plant hemicellulose fractions and $\beta$ linked glucose polymers. Biochem. J. 95, 758-766.

1959 The nutritive value of forages with emphasis on the polysaccharide fraction. Grasslands Bull. 173-185.

1950 Some relationships between chemical composition, nutritive value and intake of forages grazed by steers and wethers. J. Anim. Sci. 9, 354-362.

1950 Some effects of forage composition on its nutritive value when cut and fed green to steers and wethers, as determined conventionally and by the lignin ratio. J. Anim. Sci. 9, $531 \_539$.

1962 The relationship between the cell-wall constituents of roughages and the digestibility of the organic matter. J. Agric. Sci. $59,369-373$.

1965 Comparison of the hemicelluloses from plants belonging to two different plant families. Phytochemistry 4, 631-634.

1965 The action of rumen bacterial hemicelluloses on pasture plant hemicellulose fractions. J. Agric. Sci. 64, 449_454.

1961 Analyse des constituants glucidiques des plantes fourragères. Ann. Biol. Anim. Biochem. Biophys. 1, 163-212.

1964 Digestibilité des constituants du ray-grass anglais $S 24$ et du dactyle $\mathbf{S} 37$, plus spécialement des constituants glucidiques. Ann. Zootech. 13, 117-150.

1943 Metabolism trials with New Zealand feeding stuffs. IV. The relative significance of lignin, cellulose and crude fibre in the evaluation of feeds. N.Z. J. Sci. Tech. 25 A, 137-151.

1960 Neue Untersuchungen über den Einflusz der pflanzlichen Gerüstsubstanzen auf die Verdaulichkeit von Grünfutterstoffen. Arch. Tierernähr. 10, 99-112.

1963 Digestibility of the alpha cellulose and pentosan components of the cellulosic micelle of fescue and alfalfa. J. Nutr. 79, $105-108$.

1965 Influence of hemicellulose $A$ and $B$ on cellulose digestion, volatile fatty acid production and forage nutritive evaluation. J. Nutr. 85, 89-101.

1963 Use of detergents in the analysis of fibrous feeds. J. Ass. Off. Agric. Chem. 46, 825-829.

1965 Comparison of two different equations for prediction of digestibility from cell contents, cell-wall constituents and lignin content of acid detergent fibre. J. Dairy Sci. 48, 815.

1955 Cellulose and lignin in forage grasses and their digestion coefficients. J. Anim. Sci. I4, 710-717. 
WAITE, R.,

JoHNSTON, M. J. and Armstrong, D. G.
1964 The evaluation of artificially dried grass as a source of energy for sheep. The effect of stage of maturity on the apparent digestibility of rye-grass, cocksfoot and timothy. J. Agric. Sci. $62,391-398$. 